\title{
Geological controls on BSR occurrences in the incipient arc-continent collision zone off southwest Taiwan
}

\author{
Che-Chuan Lin ${ }^{a}$, Andrew Tien-Shun Lin ${ }^{\mathrm{a}, *}$, Char-Shine Liu ${ }^{\mathrm{b}}$, Guan-Yu Chen ${ }^{\mathrm{a}}$, Wei-Zhi Liao ${ }^{\mathrm{a}}$, \\ Philippe Schnurle ${ }^{\mathrm{b}}$ \\ a Institute of Geophysics, National Central University, Jhongli, Taiwan \\ ${ }^{\mathrm{b}}$ Institute of Oceanography, National Taiwan University, Taipei, Taiwan
}

\section{A R T I C L E I N F O}

Article history:

Received 21 February 2008

Received in revised form

1 November 2008

Accepted 4 November 2008

Available online 18 November 2008

\section{Keywords:}

Bottom simulating reflectors

Gas hydrates

Offshore SW Taiwan

Tectonic features

\begin{abstract}
A B S T R A C T
Bottom simulating reflectors (BSRs) observed on seismic sections are often considered as indicators for the existence of free gas, delineating the base of the gas hydrate stability zone. Abundant BSRs seen on seismic sections acquired off the SW coast of Taiwan indicate the likely and prevalent existence of gas hydrates in the study area. This study aims to characterize the occurrence of BSRs off SW Taiwan and to understand their relationship to topography, tectonic activity, and possible migration paths of gasbearing fluids in this area.

The tectonic setting off SW Taiwan is during the initial stage of arc-continent collision between the Luzon arc and the northeastern continental margin of the South China Sea. A series of west-vergent, imbricated folds and emergent thrusts develop in the accretionary wedge. Each fold-and-thrust sequence corresponds to an elongated submarine ridge if its crest is not buried by flat-lying sediments. By contrast, normal faulting prevails in the northeastern margin of the South China Sea.

A correlation between distribution of BSRs, topography, and tectonic features can be observed. Four major occurrences of BSR types of ridge type, basin type, submarine-canyon type, and continental slope type, are recognized on the basis of the relationship of BSRs to topographic and structural features. Main characteristics of BSRs in the study area can be described as: (1) they occur mostly beneath topographic highs; (2) a discordant relationship between surfaces of the seafloor and underlying strata where BSRs are present; (3) BSRs are prevalent especially beneath the crest and flank of the upthrusting, large and inclined slope basins; and (4) in general, a series of high-amplitude dipping reflectors beneath BSRs can be found. These features indicate that gas hydrate may accumulate preferably beneath topographic ridges especially underneath four-way-dip topographic closures. This effect may exist because the buoyancy-driven, gas-bearing fluids tend to migrate upward and laterally toward structural highs and their corresponding topographic ridges.

The distribution of BSRs indicates that gas hydrates occur more commonly in the accretionary wedge than in the South China continental margin. We suggest that the more widespread occurrence of gas hydrates in the accretionary wedge is due to the existence of multiple fault zones, which may help to tap more deep-seated gas-bearing fluids, in addition to the shallow biogenic gas, in this region.
\end{abstract}

(C) 2008 Elsevier Ltd. All rights reserved.

\section{Introduction}

Bottom simulating reflectors (BSRs) seen on seismic reflection profiles are conventionally interpreted as indicators for the base of gas hydrate stability zone (GHSZ) and hence indicate the possible presence of gas hydrate and free gas beneath the seafloor (Dillon and Paull, 1983; Miller et al., 1991). Gas hydrates and their

\footnotetext{
* Corresponding author. Institute of Geophysics, National Central University, No. 300, Jhongda Road, Jhongli City, Taoyuan County 32001, Taiwan. Tel.: +886 3422 7151x65618; fax: +8863422 2044 .

E-mail address: andrewl@ncu.edu.tw (A. Tien-Shun Lin).
}

associated BSRs have been retrieved or recognized either in accretionary wedges (e.g., Riedel et al., 2006; Ashi et al., 2002; Colwell et al., 2004) or in rifted continental margins (e.g., Holbrook et al., 1996; Paull et al., 1998). These two drastic different tectonic settings seldom exist in close proximity. Offshore southwest Taiwan (Fig. 1), an accretionary wedge has obliquely overridden the rifted South China continental margin (Liu et al., 1997). A few studies have documented the prevalent existence of BSRs off southwest Taiwan both in the accretionary wedge (e.g., Reed et al., 1992; Lundberg et al., 1992; Chi et al., 1998, 2006; Shyu et al., 1998; Schnurle et al., 1999; Chow et al., 2000; Liu et al., 2006) and in the South China continental slope (e.g., Chi et al., 1998; McDonnell 


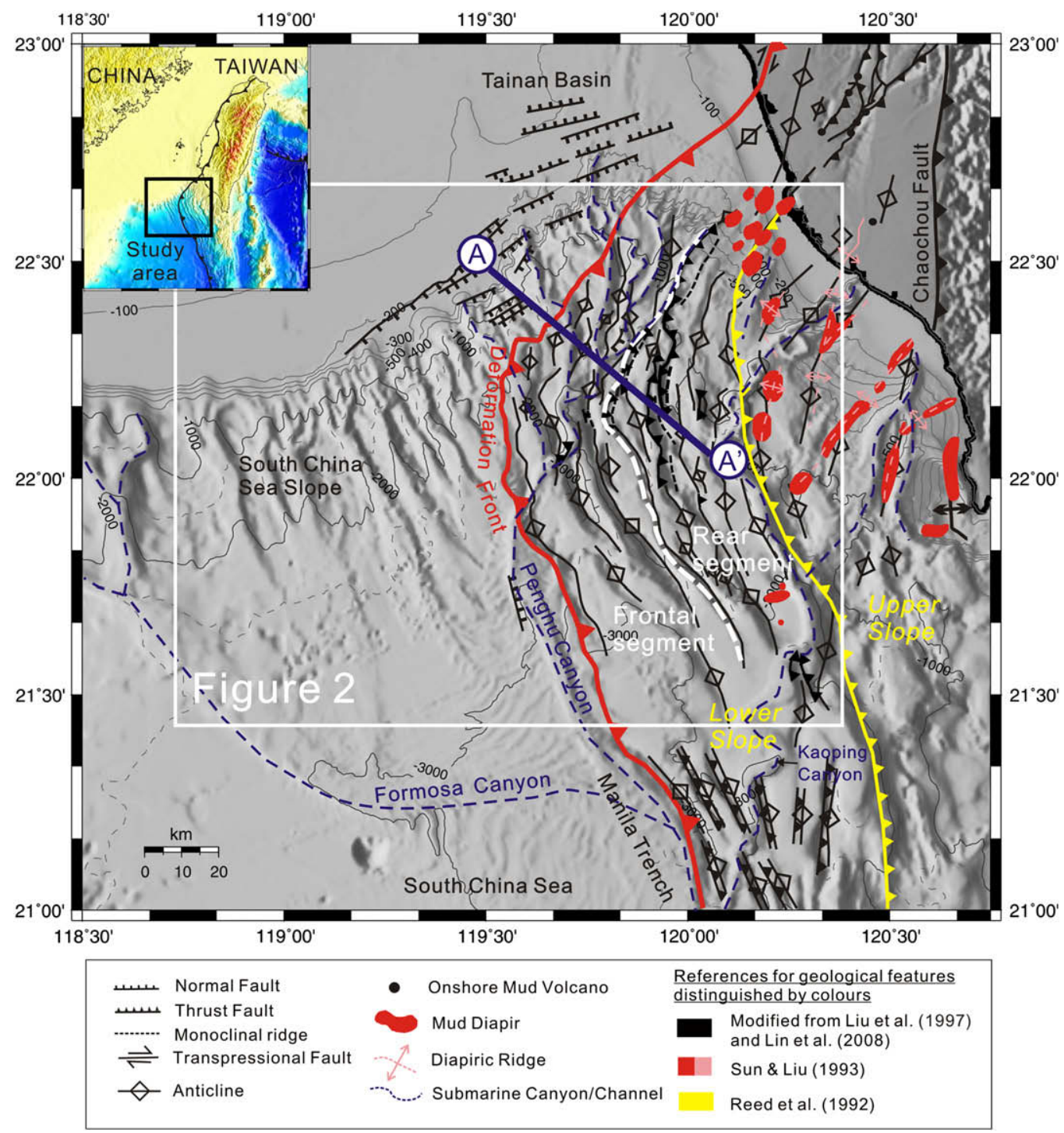

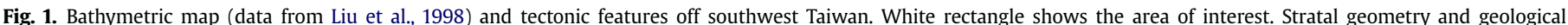

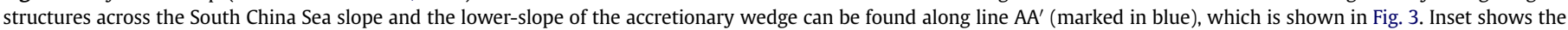
location map of the study area. Barbed red line shows the front of compressive structures (deformation front).

et al., 2000; Liu et al., 2006). The juxtaposition of an accretionary wedge on top of a rifted continental margin, such as the case off SW Taiwan, offers us a rare opportunity to compare and contrast the BSR occurrences in the above two tectonic settings.

The Central Geological Survey of Taiwan initiated a research program in 2004 to explore the gas hydrates offshore southwestern Taiwan. In this program, several geophysical methods were employed to explore the distribution and physical properties of gas hydrate-bearing sediments. The geophysical approaches include multichannel seismic (MCS) reflection profiling (e.g. Liu et al., 2006), chirp-sonar sub-bottom imaging (e.g. Chiu et al., 2006), refraction seismic studies (e.g. Cheng et al., 2006; Schnurle et al., 2006), heat-flow measurements (e.g. Shyu et al., 2006), gravity and magnetic surveys. Among the above studies, over 10,000 line-km of MCS profiles at a line spacing of $\sim 1.86 \mathrm{~km}$ ( $1 \mathrm{arc}$ min) have been collected. On the basis of this MCS dataset, Liu et al. (2006) mapped out the BSR distribution both in the accretionary wedge and in the South China Sea continental slope in a water depth ranging from 500 to over $3000 \mathrm{~m}$. They also pointed out that BSRs are present on nearly $50 \%$ of the collected seismic lines. In parallel to the geophysical studies, a suite of geological/geochemical studies funded by the Central Geological Survey of Taiwan has been carried out in the same region to investigate the anomalous features near the seabed that may serve as proxies for the existence of gas hydrates beneath the seafloor.

All the above studies have pointed to a likely wide occurrence of gas hydrates both in the accretionary wedge and in the South China continental margin. In this paper, we analyzed the $\sim 10,000$ line$\mathrm{km}$ MCS data, and categorize the occurrence of BSRs according to their characteristics and their relationships to topographic and tectonic features. For the detailed descriptions of geological structures, interested readers may refer to a companion paper of Lin et al. (2008).

In this paper, we start by describing the major occurrences of BSRs and their associated topographic and geological features in the study area. On the basis of these BSR occurrences and available geochemical/geophysical studies, we then address the possible sources of gas that may form the gas hydrates, the gas source areas, and the migration paths for gas-bearing fluids. Our results have implications for gas hydrate systems in a rifted continental margin being overridden by an accretionary wedge such as the case offshore SW Taiwan. 


\section{Data}

We examined BSRs in the areas of accretionary wedge and South China Sea continental slope off SW Taiwan using 115 MCS profiles shown in Fig. 2. Seismic grids of MCS647, MCS681 are recorded using 48 channels and seismic grids of MCS716, MCS719, MCS754, and MCS764 are recorded using 24 channels, respectively. All the seismic data were collected onboard R/V Ocean Researcher I during $2002 \sim 2005$.

The channel spacing is $12.5 \mathrm{~m}$ and the seismic source was a 3airgun-array with a total volume of $475 \mathrm{in}^{3}$, which was fired at 10-s interval. The seismic signals were recorded up to $5 \mathrm{~s}$. The streamer was towed at an average ship speed of 4.86 knots, yielding 12 -fold coverage for 48 channel profiles and 6 -fold coverage for 24 channel profiles, respectively. All the seismic data were stacked and migrated. Liu et al. (2006) presented the details of seismic data processing and hence these procedures are not reproduced in this study.

\section{Tectonic setting}

The tectonic setting off southwestern Taiwan is in the initial stage of arc-continent collision (Liu et al., 1997; Huang et al., 2000) between the Luzon volcanic arc and the northern continental margin of the South China Sea (Fig. 1). The transition from plate subduction to arc-continent collision is located at about $22^{\circ} \mathrm{N}$ (Liu et al., 1992; Reed et al., 1992; Kao et al., 2000). South of $22^{\circ} \mathrm{N}$, the South China Sea oceanic lithosphere is subducting eastward beneath the Philippine Sea plate along the Manila trench. However, the Luzon arc collides with the southeastern Eurasian continental margin north of $22^{\circ} \mathrm{N}$, forming a broad orogenic wedge that includes the Taiwan orogen.
A series of west-vergent and imbricated folds and emergent thrusts develops in the accretionary wedge (Figs. 1 and 3). Reed et al. (1992) divided the accretionary wedge into upper-slope and lower-slope domains. A series of mud diapirs is found in the upperslope domain near the coast of SW Taiwan (Fig. 1, Sun and Liu, 1993; Chiang et al., 2004). The diapiric structures strike in a NE- SW direction. They can be traced to adjacent onshore structures in the fold-and-thrust belts. The presence of mud volcanoes both offshore (Chiu et al., 2006) and onland Taiwan (Yang et al., 2004, Fig. 1) indicates active fluid expulsion in the accretionary wedge. Gas analysis for onshore mud volcanoes (Yang et al., 2004) suggests that most of the gas originates from deeper crust.

In the lower-slope domain, each fold-and-thrust corresponds to an elongated submarine ridge if its crest is not buried by flat-lying sediments. Based on the structural characteristics, the lower-slope domain can be further divided into frontal and rear segments (Lin et al., 2008, Fig. 1). The frontal segment lies in the region between the deformation front and the western limit of a series of emergent thrusts. Several blind thrusts have uplifted the strata and formed a series of thrust-cored anticlines in this area. Several tributaries of the Penghu submarine- canyon develop along the synclines and in some places cut across the topographic ridges cored by anticlines. The rear segment lies in between the westernmost emergent thrusts in the west and the Kaoping Canyon in the east. Westvergent emergent thrusts and anticlines prevail in this area. Several homoclinal ridges are formed as a result of the tilting and uplifting of the eastward-dipping hangingwall strata of emergent thrusts. On top of each thrust sheet has been developed a slope basin.

The strike of the deformation front and fold-and-thrust structures trends in an NE-SW direction in the north and turns into an N-S direction toward the south while the number of emergent thrusts decreases. By contrast, the structural fabric of the Tainan basin to the

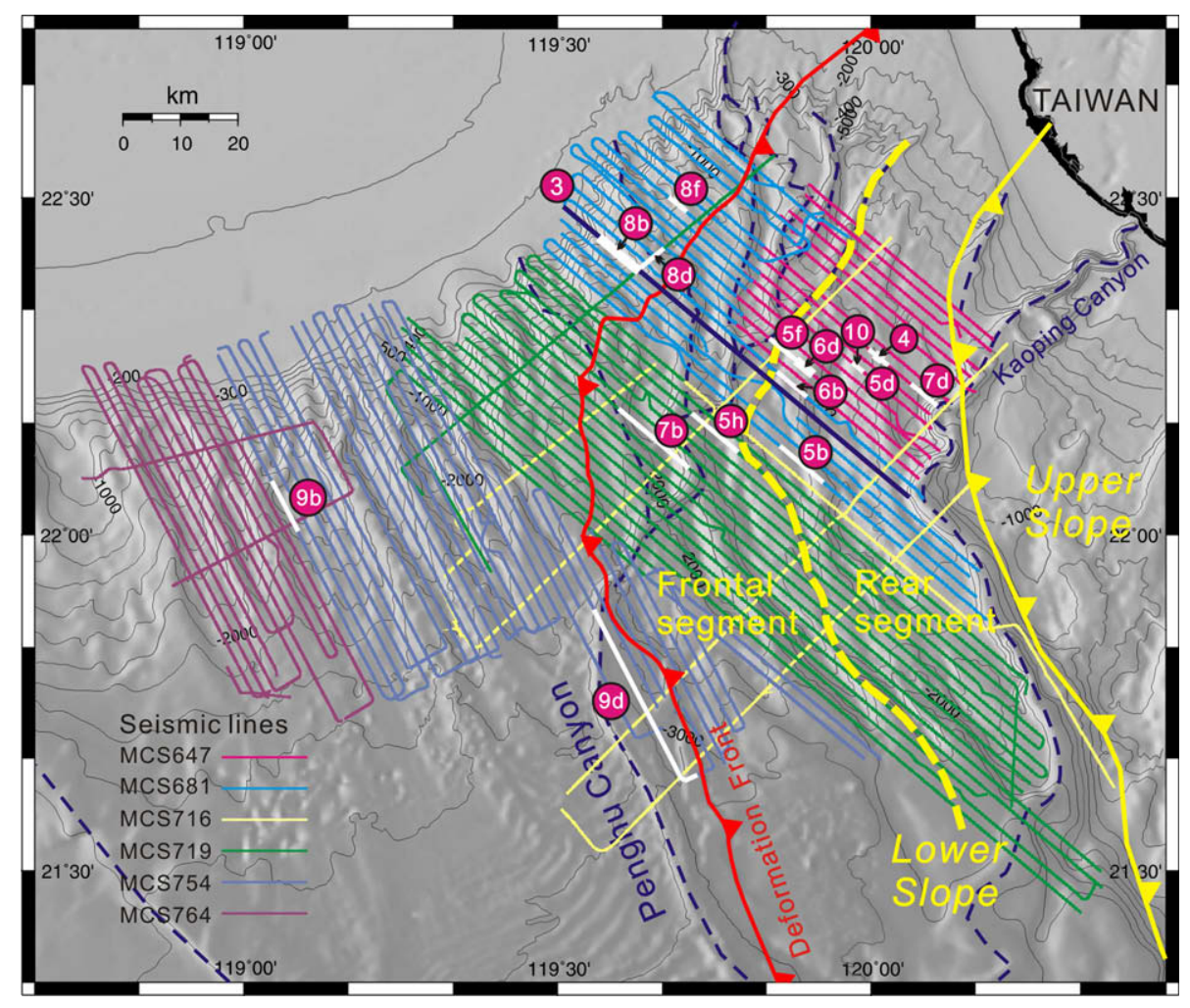

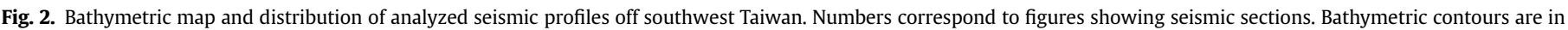
meter. 

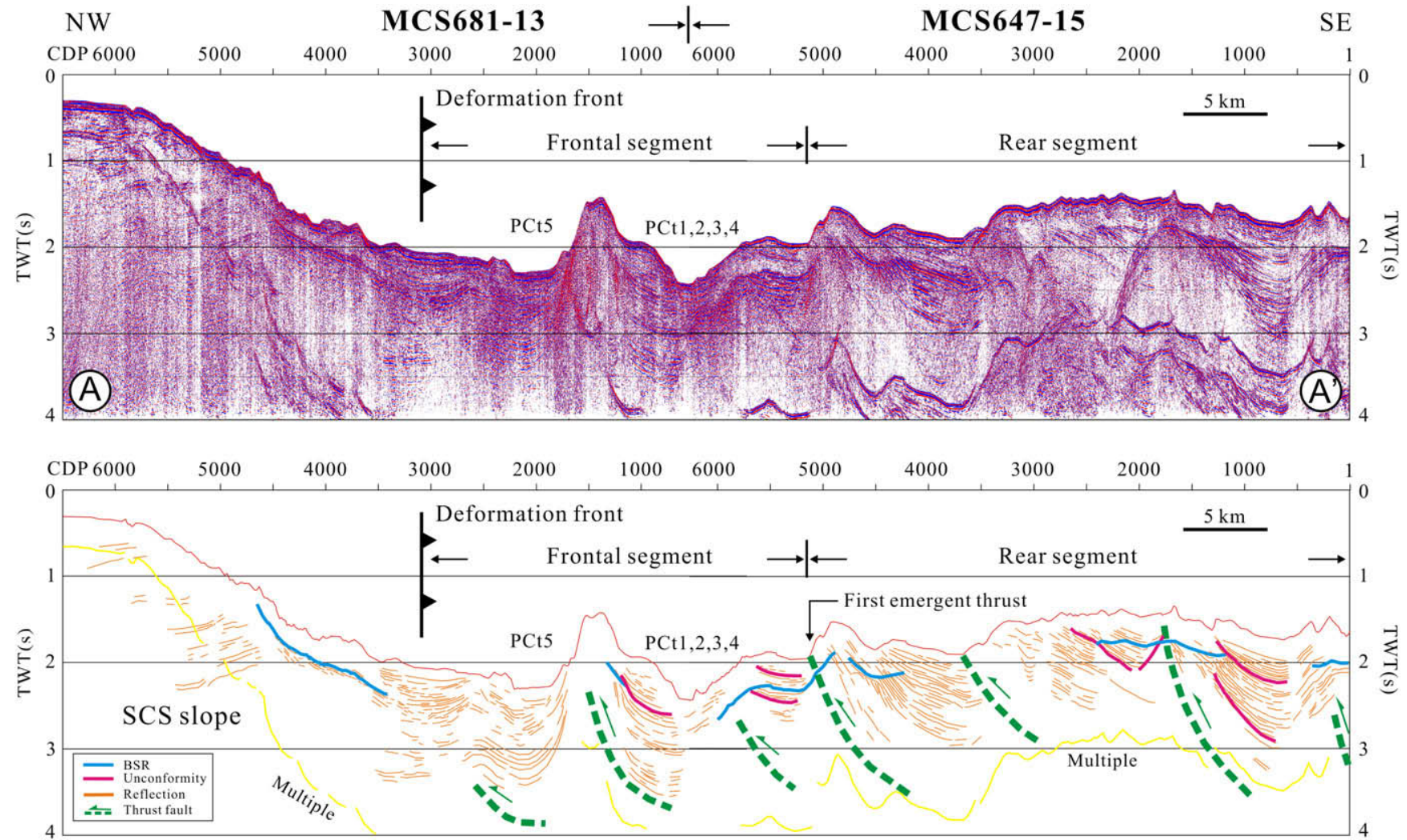

Fig. 3. Uninterpreted seismic reflection profile (above) and interpreted profile (below) showing structural styles and BSR (marked in blue in the lower panel) distributions in the accretionary wedge and continental slope. Profile location is shown in Figs. 1 and 2. PCt indicates the tributary of Penghu submarine -canyon and the number indicates the name of tributary used in this study. Abbreviations: CDP: common depth points. TWT: two-way travel time (seconds) of seismic waves.

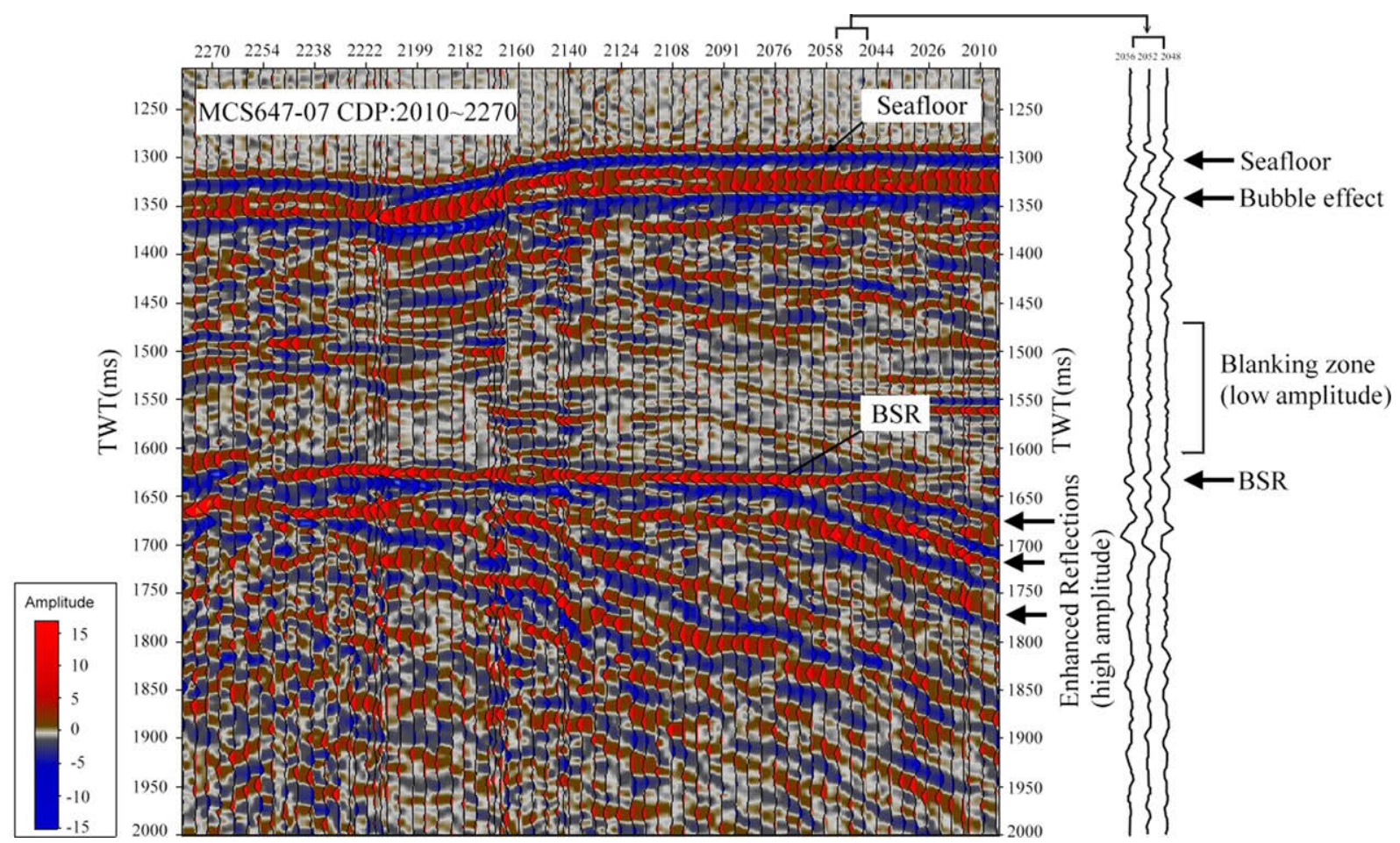

Fig. 4. A portion of the seismic profile, MCS647-7, in the study area, showing BSR and its associated blanking zone above, along with high-amplitude reflections below. The left box shows the amplitude scale with blue color representing positive reflection coefficient and red color indicating negative reflection coefficient. The minimum-phase wavelets on the right show example seismic amplitudes and their interpretation. Note that the phase of waveform of BSR is reverse to that of the seafloor. 
west of deformation front is characterized by a series of ENE-trending normal faults (Fig. 1, Yang et al., 1991; Liu et al., 1997). A major growth normal fault exists in the northern margin of the South China Sea near the shelf break (Fig. 1; Lin et al., 2003). The faulting has tilted the hangingwall strata to the NW direction and has resulted in the stratal truncation beneath the slope (Fig. 3). This normal faulting dies out to the southwest, and sediments there show a prograding and aggrading wedge beneath the outer shelf and upper-slope. The seafloor

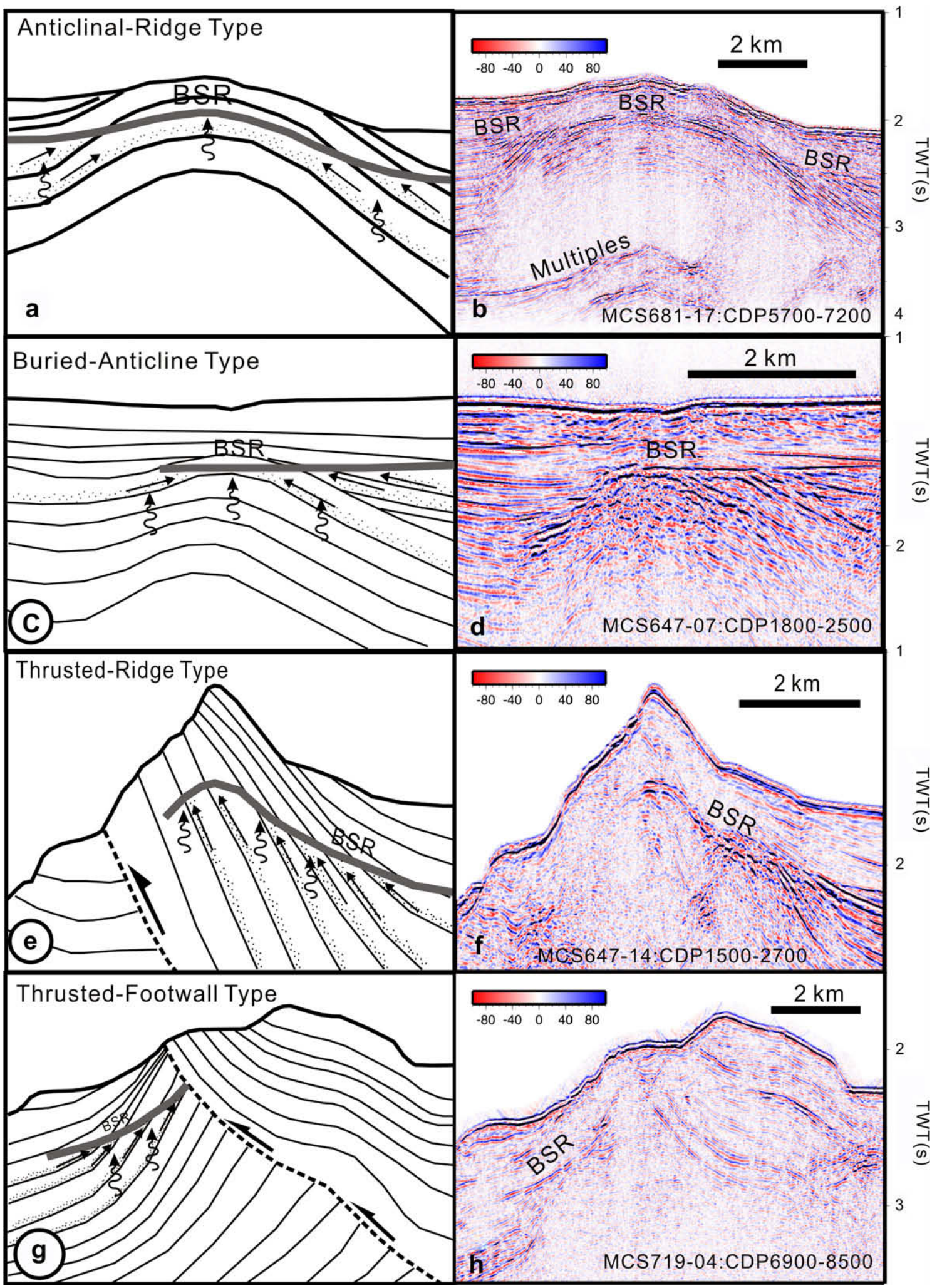

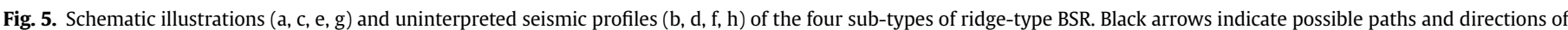

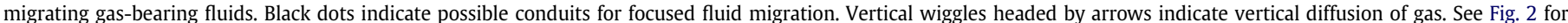
profile locations. The red-to-blue scale denotes the seismic amplitude. 
physiography in the slope area is dominated by small erosional gullies perpendicular to the strike of slope.

\section{BSR distribution patterns in the accretionary wedge and continental slope}

Fig. 4 shows, for example, a characteristic BSR and its associated features in the study area. The characteristic BSR is sub-parallel to the seafloor and often cuts across primary stratal reflections. There is commonly a blanking zone (i.e., low amplitude reflections) above the BSR probably because of the presence of gas hydrates (e.g., Dillon et al., 1993; Lee and Dillon, 2001). The reflection polarity of BSR is reverse to that of the seabed (e.g., Hyndman et al., 2001); this is because seismic waves pass through the gas hydrate layer of relatively high velocity above the BSR to a relatively low-velocity layer below, which contains free gas (e.g. Yuan et al., 1999; Ecker et al., 1998). By comparison, seismic waves transmit from low-velocity seawater to relatively higher velocity sediment across the seafloor. Generally, there exists a series of high-amplitude dipping reflectors beneath BSRs. Accumulation of free gas below the gas hydratebearing sediments is frequently invoked to explain the high-amplitude anomalous reflectors beneath BSRs (e.g., Bryan, 1974).

We categorized BSRs according to their relationship to topography, structural features, and relative positions to geological elements (e.g., basin margins, basin centers, etc.) into four BSR types: ridge type, basin type, submarine-canyon type, and continental slope type, respectively (Figs. 5-9). The former three occur mainly in the accretionary wedge (Fig. 11), and the latter lies in the South China Sea continental slope in the study area (Figs. 11 and 12). Similar BSR classifications can be found in the Nankai accretionary prism of Japan (Baba and Yamada, 2004).

\subsection{Ridge-type BSR}

Ridge-type BSR (Fig. 5) indicates that the BSR develops within a compressional structure cored by anticlines or thrust faults. This
BSR type can be further divided into four categories: anticlinalridge type, buried-anticline type, thrusted-ridge type, and thrusted-footwall type (Fig. 5). Anticlinal-ridge type BSR indicates that the BSR develops beneath the crest of an active anticlinal ridge (Fig. 5a,b). The areal extent of this BSR type is far more widespread than other ridge-type BSRs. Buried-anticline type BSR is found beneath inactive anticlinal structures, which are covered by more or less horizontal strata and show no geomorphic surface expression (Fig. 5c,d). Thus, the BSR cuts across the strata in both inclined limbs of inactive anticlines because the BSR is sub-parallel to the overlying and flat seabed. Thrusted-ridge type BSR develops in the hangingwall of the thrust fault that forms a bathymetric ridge (Fig. 5e,f). In contrast, thrusted-footwall type BSR appears in the footwall strata of the thrust fault (Fig. 5g,h).

\subsection{Basin-type BSR}

Basin-type BSR (Fig. 6) is formed along the margins of slope basins on the hangingwall of thrusts. Sometimes, the BSR also exists in the interior of basins. We therefore divided the basin-type BSR into the basin-margin type and the intra-basin type (Fig. 6a-d).

The dip angle of inclined beds in the margins of slope basins is often higher than that in the interior of basins. It is therefore difficult to distinguish the presence of a BSR from strata in the interior of basins because the stratal reflections are often parallel to the seabed. Still, many continuous BSRs are found in the interior of basins in the rear segment of accretionary wedge where the seafloor and underlying stratal reflections are sub-parallel, such as the case shown in Fig. 6d. We therefore distinguish BSRs from stratal reflections based on features that BSRs are parallel to the seabed but cut across stratal reflections. This type of BSR is called intra-basin type BSR (Fig. 6c,d).

\subsection{Submarine-canyon type BSR}

Submarine-canyon type BSR (Fig. 7) is rarely found, and is recognized in the margins or channel floors beneath submarine

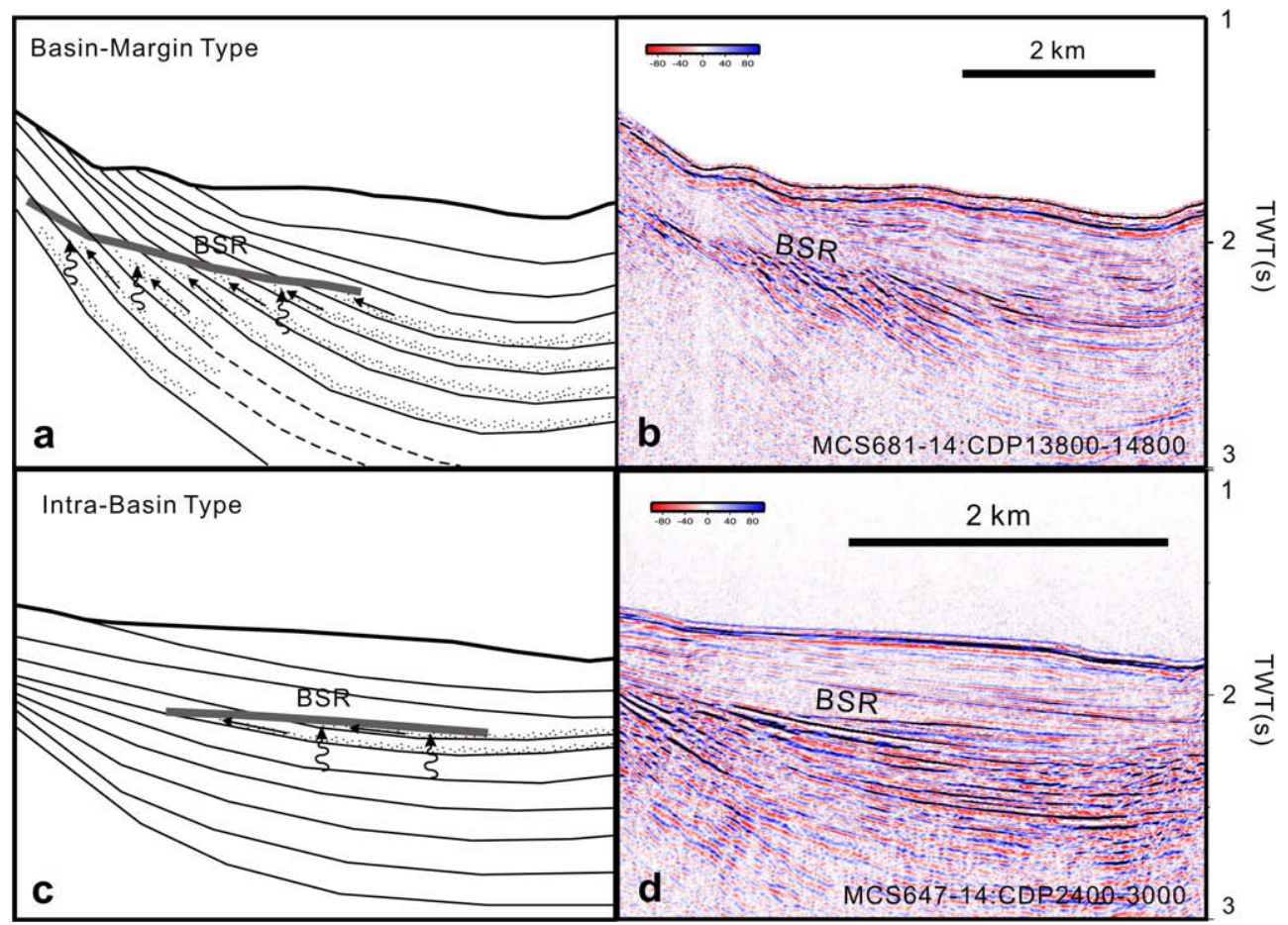

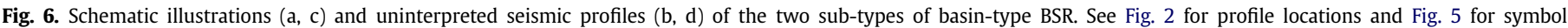
explanations. 


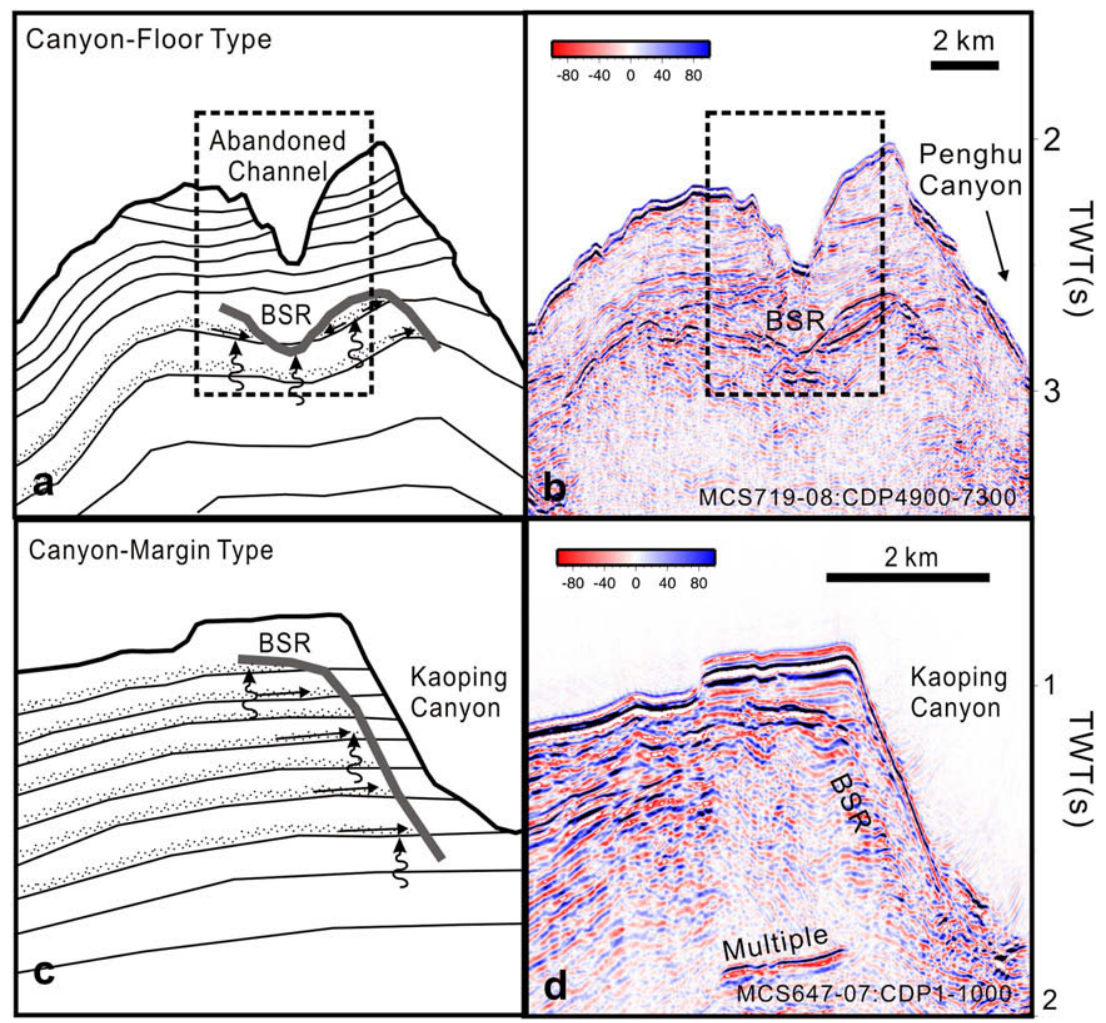

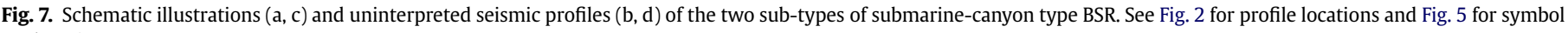
explanations.

-canyons, so that the submarine-canyon type BSR can be divided into canyon-floor (Fig. 7a,b) and canyon-margin (Fig. 7c,d) types of BSR. Canyon-floor type BSR is the rarest of all types. They appear beneath canyons where the seafloor and underlying stratal reflections are discordant. One example is shown in Fig. 7a,b. There is an "apparent syncline" formed beneath an uplifted and abandoned channel. The apparent syncline is formed because the water velocity of seismic waves in the abandoned channel is lower than the sediment velocity in adjacent channel walls. Tucker and Yorston (1973) coined the lateral velocity variation due to channeling processes as "velocity anomaly", which often produces "apparent synclines" beneath channels. For this reason, the arrangement of these stratal reflections on the seismic section looks like a syncline; in fact, these strata may be parallel or even in an anticlinal form (Fig. 7a,b).

Canyon-margin type BSRs are mainly developed in the west bank of Kaoping canyon (Fig. 11). The strata, where this type of BSR is observed, are dipping away from the canyon axis (Fig. 7c,d).

\subsection{Continental slope type BSR}

Continental slope type BSRs (Figs. 8 and 9) occur in the South China Sea continental slope to the west of the deformation front. This BSR type is often located under erosional remnant ridges, but many BSRs are even found beneath erosional gullies especially in the NE corner of the slope. Based on the locations of BSRs, we divide continental slope type BSR into five sub-types: slope-ridge type, slope-trough type, frontal slope-front-fill type in the NE half of the slope (Fig. 8a-f) as well as erosional-ridge type and distal-slope type in the SW half of the slope (Fig. 9a-d).

In the NE half of the continental slope and near the accretionary wedge, we differentiated the slope-ridge type and slope-trough type BSR more easily as the seismic lines run obliquely across the ridges/gullies (Fig. 8a,c). For seismic profiles that are parallel to the axes of ridges/gullies, both of these two BSR types share similar characteristics, i.e., inclined strata being truncated beneath the slope. The stratal truncation beneath the seafloor is associated with the oceanward-dipping normal fault near the shelf break, which cuts through Oligocene to recent sediments and tilted hangingwall strata shelfward. The slope-trough type BSR in the section perpendicular to the gully is similar to canyon-floor type BSR (Figs. $7 \mathrm{~b}$ and $8 \mathrm{~d}$ ), but their origins are different as we mentioned above (Figs. 7a and 8c). In addition, frontal slope-front-fill type BSR is situated between the area of slope front fill and continental slope (Fig. 8e,f).

In the southwest Tainan slope, BSRs occur mainly beneath remnant erosional ridges (Fig. 9a,b). Deeper BSRs are present beneath the distal slope near the South China Sea abyssal plain (Fig. 9c,d).

\subsection{Blanking without BSR}

In some parts of studied seismic profiles, a BSR is not observed, but zones of low seismic amplitude (blanking zone) beneath the seafloor and above the possible depth if BSRs are observed (Fig. 10). A blanking zone is a zone of reduced seismic amplitude caused by the reduction of acoustic impedance between sediment layers. The blanking zone may result from two causes, namely the presence of gas hydrates (e.g., Shipley et al., 1979; Lee and Dillon, 2001), and the homogeneity of sediments (e.g., Holbrook et al., 1996). The following two reasons prompt us to believe that the blanking zones may be due to the presence of gas hydrates. First, the base of blanking zones is generally close to the potential base of GHSZ as shown in Fig. 10, for example. Second, same reflectors, which cut across the potential base of GHSZ (see Fig. 10), often exhibit reduced amplitude above the potential base of GHSZ, and strong amplitude below. 


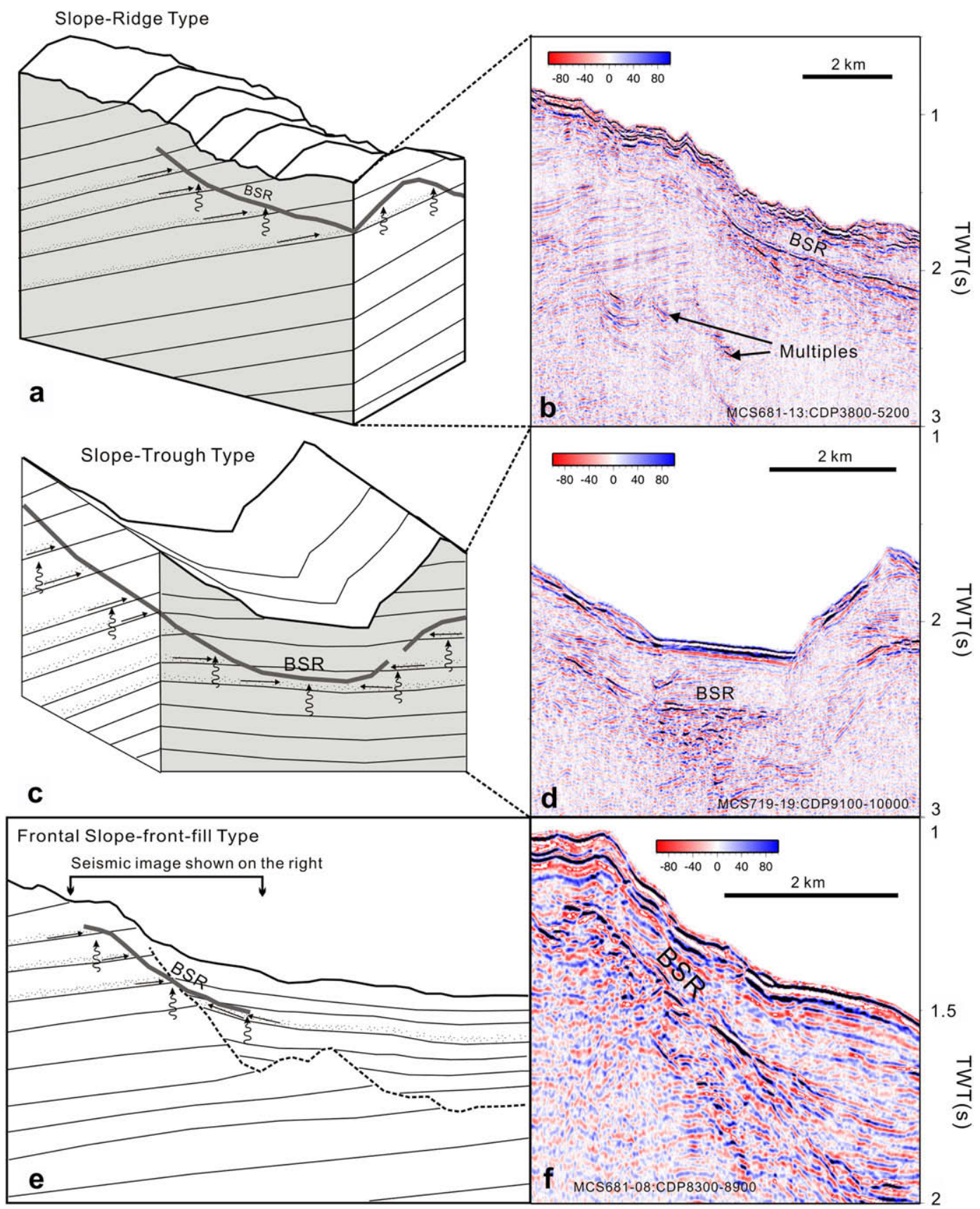

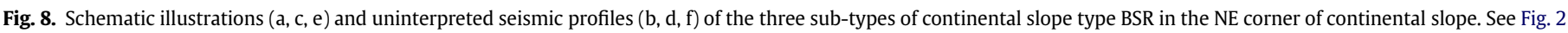

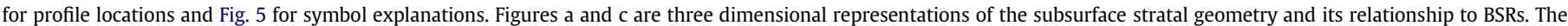
gray-shaded portions are shown in figures b and $d$, respectively.

Hydrate-bearing sediments may exist without a BSR if no free gas is trapped underneath it, similar to cases shown in the Blake Ridge (Tinivella and Lodolo, 2000; Holbrook, 2001) and in the Peru margin (Kvenvolden and Kastner, 1990). It is generally believed (e.g. Holbrook, 2001; Hyndman et al., 2001) that the impedance contrast responsible for the BSR is due to the presence of free gas below the base of hydrate stability zone instead of hydrate above. In the accretionary wedge, free gas is mainly produced by hydrate recycling mechanism (Paull et al., 1994; Pecher et al., 1996; VonHuene and Pecher, 1999). The lack of free gas beneath the GHSZ may be due to that the upward flow of under-saturated fluid depletes free gas faster than gas is produced by hydrate recycling as suggested to occur in the Svalbard continental slope (Haacke et al., 2008).

\section{Discussion}

\subsection{The nature of BSR in the study area}

We have shown above the BSR types in the study area. However, one type of BSR is not related to the gas hydrate stability zone. This type of BSR is reported to result from diagenetic transition of silica from opal A to opal C/T phase in silica-rich sediments (e.g., Kastner et al., 1977; Hein et al., 1978; Berndt et al., 2004). The positive acoustic impedance contrast between the transition from opal A above to opal CT below yields the same BSR polarity as the seafloor reflection. The above diagenetic transformation is likely to occur in siliceous sediments of biogenic origin (e.g., oozes, Kastner et al., 


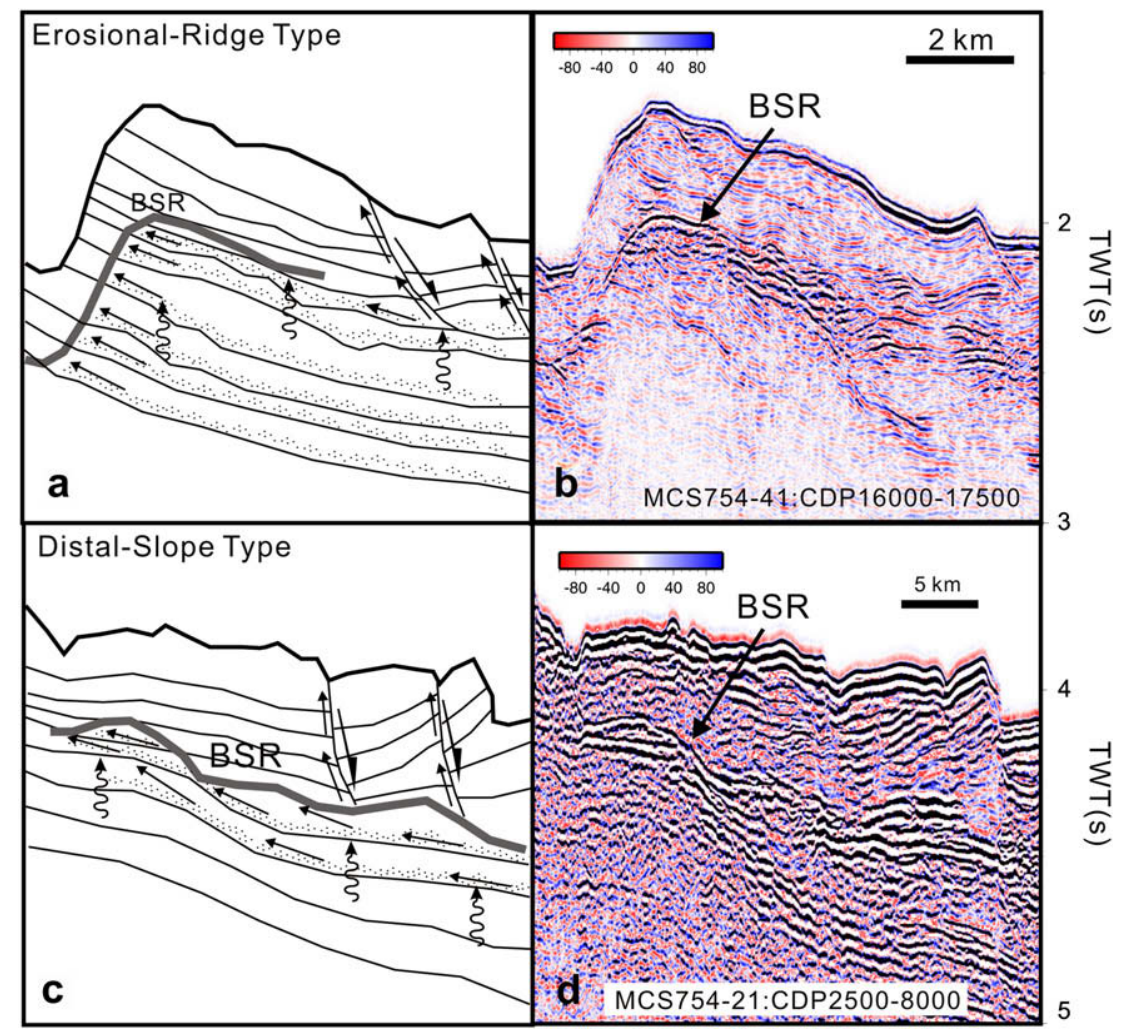

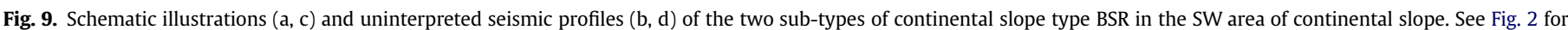
profile locations and Fig. 5 for symbol explanations.

1977) and therefore this type of BSR is reported to exist in passive continental margins with slow rate of sedimentation (e.g., Berndt et al., 2004; Lee et al., 2003). The study area off SW Taiwan is characterized by rapid sedimentation with large amounts of orogenic detritus (Yen and Lundberg, 2006) derived from the rapidly denudating Taiwan island (Dadson et al., 2003) and

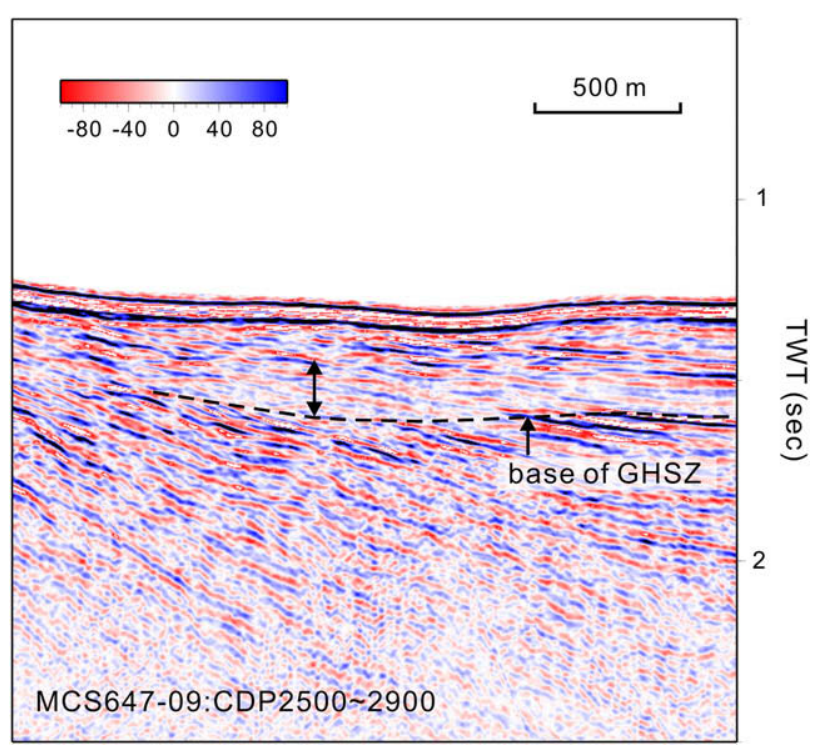

Fig. 10. Seismic section showing blanking zone (indicated by the double headed arrow) without BSR occurrence. Dashed line indicates the possible base of gas hydrate stability zone (GHSZ). See Fig. 2 for profile location. systematic analyses of seafloor sediments found no siliceous ooze (Jiang et al., 2006) in both regions of the accretionary wedge and adjacent South China Sea continental slope. For this reason we believe that the observed BSRs reported in this study are caused by free gas at the base of the GHSZ rather than diagenetic-related BSRs. In addition, where data permitted we also checked the polarity of the BSR and found that the polarity of BSR is reverse to that of the seafloor reflections, indicating that these BSRs are free gas (or gas hydrate) related features. Therefore, we believe that the BSR in the study area marks the base of GHSZ.

There are additional indicators that point to the BSRs as free gas or gas hydrate related features: (1) there exist enhanced reflections beneath BSRs, indicating the presence of free gas trapped beneath the GHSZ; (2) the experiments of ocean bottom seismometers in the areas, where BSRs are revealed both in the accretionary wedge (Cheng et al., 2006; Schnurle et al., 2006) and in the continental slope (Wang et al., 2006), show an increase of P-wave velocity above the BSR and a decrease of velocity underneath, suggesting the presence of free gas beneath BSR; and (3) in a few locations, the presence of BSRs is associated with methane-venting features seen at the seafloor. For instance, a series of studies has found geochemical anomalies, such as extremely high methane concentration in the sediment pore water and bottom water (Chuang et al., 2006), shallow sulfate/methane interface and rapid decrease of sulfate in pore water (Lin et al., 2006), the existence of authigenic carbonates at the seafloor (e.g., Lin et al., 2006) and in sediment cores (e.g., Huang et al., 2006), and the occurrences of greigite (Horng and Chen, 2006), pyrite (Huang et al., 2006; Jiang et al., 2006) along with tubeworms of Pogonophora (Huang et al., 2006). The locations of these findings are consistent with our mapped BSRs distribution, suggesting the likely existence of gas hydrates beneath the seafloor of the study area. 


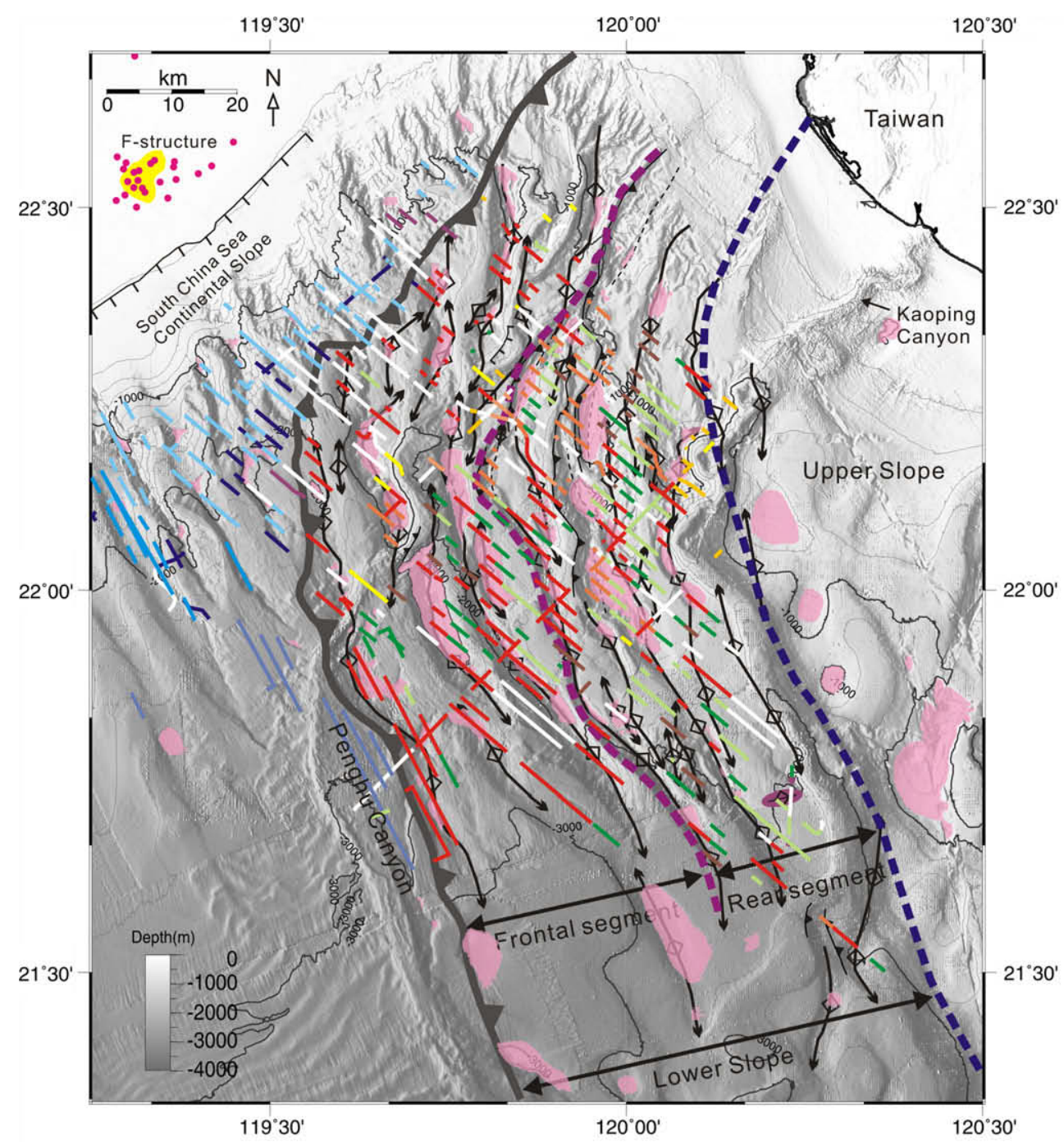

\begin{tabular}{|c|c|c|c|}
\hline Ridge Type & Basin Type & $\theta$ & anticline \\
\hline Anticline-Ridge Type & \multirow{3}{*}{$\begin{array}{l}\text { Basin-Margin Type } \\
\text { Intra-Basin Type } \\
\text { Submarine Canyon Type }\end{array}$} & $\triangle 1$ & thrust \\
\hline Buried-Anticline Type & & -- & crest of \\
\hline Thrusted-Ridge Type & & 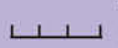 & normal fault \\
\hline Thrusted-Footwall Type & Canyon-Floor Type & $\theta$ & diapirs \\
\hline Continental Slope Type & Canyon-Margin Type & & deformation front \\
\hline Slope-Ridge Type & \multirow{2}{*}{$\begin{array}{l}\text { Blanking without BSRs } \\
\text { (or BSRs parallel to strata) }\end{array}$} & ค & $\begin{array}{l}\text { Petroleum exploration } \\
\text { wells }\end{array}$ \\
\hline Slope-Trough Type & & 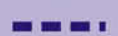 & Boundary between upper \\
\hline Frontal Slope-Front-Fill Type & \multirow{2}{*}{$\begin{array}{l}\text { Topographic } \\
\text { Closure Area }\end{array}$} & & $\begin{array}{l}\text { and lower accretionary } \\
\text { wedge }\end{array}$ \\
\hline $\begin{array}{l}\text { Erosional-Ridge Type } \\
\text { Distal-Slope Type }\end{array}$ & & $= \pm=$ & $\begin{array}{l}\text { Boundary between frontal } \\
\text { and rear segments of the } \\
\text { lower accretionary wedge }\end{array}$ \\
\hline
\end{tabular}

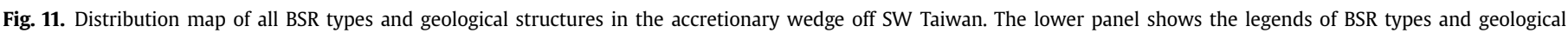
structures. The topographic highs with closed contours are shaded in translucent pink color. The thermogenic gas field beneath the shelf, F-structure, is color-coded in yellow.

\subsection{Spatial variability of BSR}

Our results show that the BSRs are widespread in the accretionary wedge and continental slope, which is consistent with the results of Liu et al. (2006) based on the same dataset. However, this study differs from Liu et al. (2006)'s results in a few aspects. First, the BSRs reported in this study only covered about 30\% of the studied seismic lines in the accretionary wedge and $20 \%$ in the continental slope. The BSR coverage is therefore much less than $50 \%$ as suggested by Liu et al. (2006). More precisely, in the accretionary wedge, BSRs cover about $35 \%$ of the studied seismic lines in the rear segment and $\sim 28 \%$ in the frontal segment. We calculated the area with the BSR occurrence within the seismic data coverage, which is around $\sim 12,000 \mathrm{~km}^{2}$, according to the percentage of BSR observed along seismic lines. Our calculations show that BSRs may occupy an area of $\sim 1152 \mathrm{~km}^{2}$ in the rear segment, $\sim 880 \mathrm{~km}^{2}$ in the frontal segment, and $\sim 1110 \mathrm{~km}^{2}$ in the rifted continental margin. Those numbers are important parameters for evaluating gas hydrate reserves in the study area in the future. Second, the upper limit of water depth for BSR existence is almost exclusively around $1000 \mathrm{~m}$, 


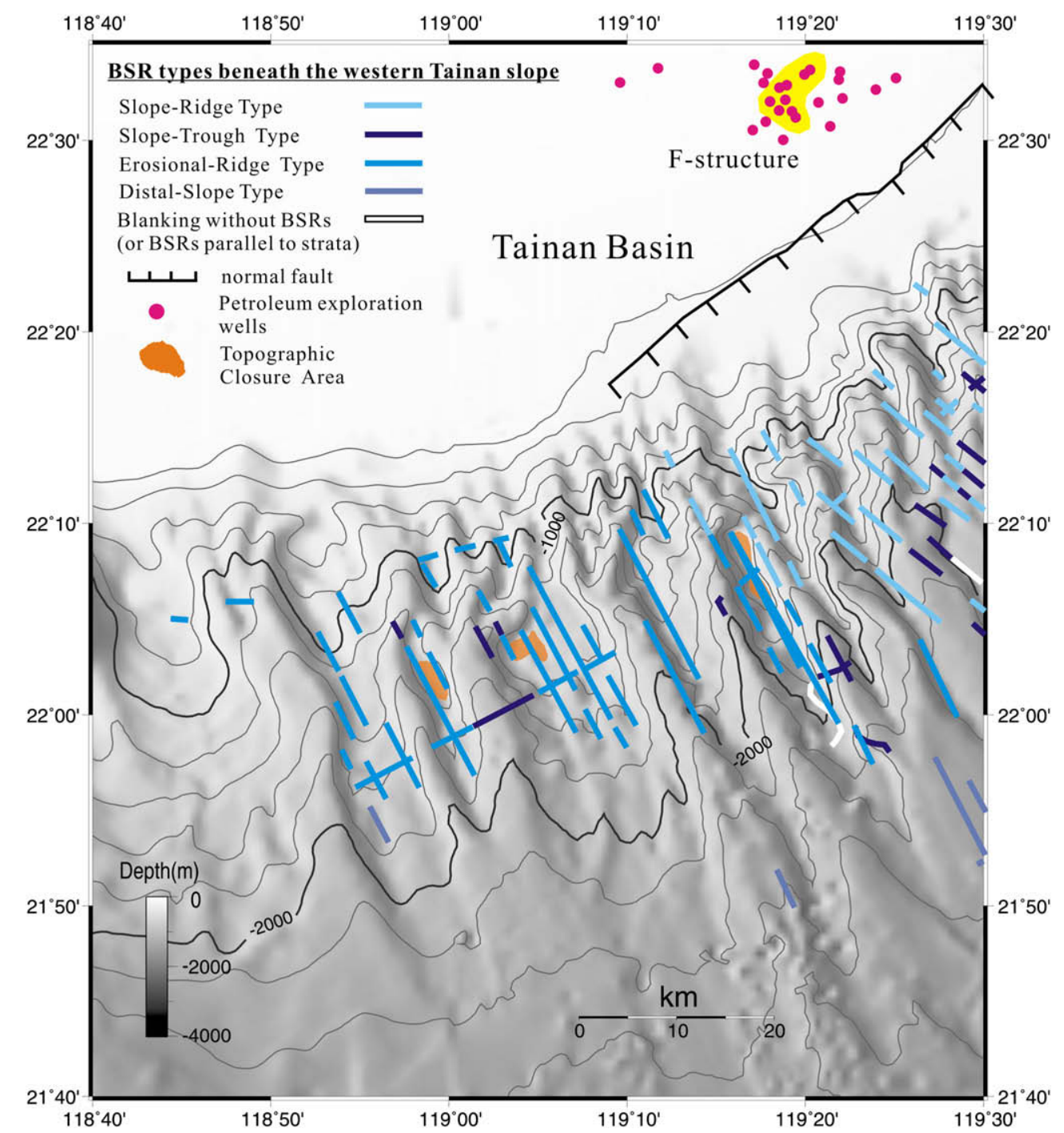

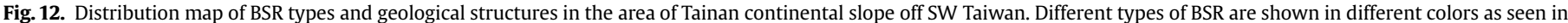
the legend. The topographic highs with closed contours are shaded in orange color. The thermogenic gas field, F-structure, is shaded in yellow color.

which is deeper than $500 \mathrm{~m}$ as suggested by Liu et al. (2006). At a few places in the accretionary wedge near Taiwan, BSRs exist at shallower depths (up to $800 \mathrm{~m}$ ). Third, our BSR distribution is similar to the distribution of classes A and B BSRs, reported in Liu et al. (2006). The classes A and B BSRs show high-amplitude reflections that cut across stratal reflections and parallel to the seafloor reflection (Liu et al., 2006). They also reported that these two classes of BSRs usually reveal under the anticlinal ridges and their adjacent slope basins in the accretionary wedge as well as beneath the slope ridges in the rifted continental margin. These observations are consistent with our study for BSR classifications of ridge type, basin type, and continental slope type. More importantly, the BSRs of classes C and D of Liu et al. (2006) are generally not considered as BSRs in this study. The class C BSRs appears to be subparallel to the seabed, making it difficult to differentiate BSRs from stratal reflections. The class D BSRs of Liu et al. (2006) exhibit week reflections and still subparallel to the sea bed. In addition, most of the class D BSRs are found beneath the upper-slope shallower than $1000 \mathrm{~m}$, or beneath the distal slope of the South China continental margin (Liu et al., 2006). Because of the large uncertainties of the BSR identification for classes C and D of Liu et al. (2006), we therefore do not consider the above two classes of BSRs as true BSR reflections.
We plot the distribution of BSR types on the structure map (Figs. 11 and 12). The BSRs are more continuous and widespread in the accretionary wedge than in the South China Sea continental slope (see Figs. 11 and 12). Fig. 11 shows that abundant BSRs develop especially in the rear segment of accretionary wedge. Many continuous BSRs exist beneath either topographic or structural highs or beneath synclines and slope basins in this region, with many BSR types. Among them, ridge type and basin type are the major ones. Canyon-margin type BSRs are present in the west bank of Kaoping canyon, but only limited canyon-floor type BSRs are found along the courses of canyons (Fig. 11).

The amount of BSRs is reduced in the reach of the Penghu canyon and its tributaries in the frontal segment. The BSR types in the frontal segment are mainly anticlinal-ridge type and canyon-floor type (Fig. 11), but the latter type is only located near the axes of anticline under the canyon. We rarely found basin-type or buried-anticline types BSR in this area, perhaps due to the channeling or erosional process. However, the BSRs are widespread again to the south of Penghu canyon in the frontal segment. In the NE half of the Tainan slope adjacent to the deformation front, continuous BSRs exist both beneath the topographic ridges and gullies (Fig. 11). However, in the SW half of the Tainan slope (Fig. 12), BSRs are sparse and only present beneath topographic highs, such as remnant erosional ridges. 


\subsection{Fluid migration pathways}

The formation of gas hydrates is associated with the upward migration of fluids containing mostly methane gas. The source of methane gas, which forms gas hydrate, is mostly derived from microbial degradation of organic matters in shallow sediments as evidenced from studies at other gas hydrate-bearing geo-provinces (e.g., Marchesi et al., 2001; Colwell et al., 2004). There are still some contributions of thermogenic gas from deeper-seated sediments, such as the case in the Gulf of Mexico (Brooks et al., 1984; Sassen et al., 1999). Offshore southwest Taiwan, geochemical studies on seafloor sediments in the accretionary wedge indicate that methane gas is mostly of biogenic origin (Chuang et al., 2006) with minor amount of thermogenic gas contribution (Oung et al., 2006). In the Tainan basin, there exists a thermogenic gas field, the Fstructure (Figs. 11 and 12; Hu et al., 1999). The thermogenic gas may therefore contribute to the formation of gas hydrate, especially beneath the Tainan slope, under favorable conditions.

As methane gas dissolves in sediment pore water, the gasbearing fluids may migrate upward along dipping permeable sediments (e.g., sand layers) to the GHSZ and form gas hydrates (Hyndman and Davis, 1992). Damaged brittle fault zones are also good migration conduits for deep-seated, gas-bearing fluids (Caine et al., 1996). For example, studies in the Barbados accretionary wedge have shown clear evidence for migration of fluid flows along fault zones and especially along the decollement (Gieskes et al., 1990; Langseth and Moore, 1990; Shipley et al., 1995). Similar conditions for fluids migrating along fault zones and decollements have been suggested in the Nankai accretionary wedge (Moore et al., 1990), the Costa Rica accretionary wedge (Shipley et al., 1990), and the Cascadia accretionary wedge (MacKay et al., 1994). Therefore, in the accretionary wedge of southwest Taiwan, an array of thrust fault zones may help to tap more deep-seated biogenic/ thermogenic gas for the development of gas hydrates at shallow sub-bottom depths. Gas-bearing fluids may also migrate from zones of higher pressure to zones of lower pressure through diffusional processes (e.g. Mason et al., 1967). The inferred diffusion process is represented by vertical wiggles with arrow heads as shown in Figs. 5-9.

In addition, we shaded topographic highs with closed contours in pink and orange colors as shown in Figs. 11 and 12. If gas hydrates are present beneath those topographic highs, the base of gas hydrate stability zone is likely to form closed areas that mimic seafloor topography above. If these situations do occur, the less permeable gas hydrate-bearing layers may act as cap rocks which may seal free gas underneath, a situation similar to a conventional gas field featuring a four-way dip closure. We compared BSR distribution with these closure areas (Figs. 11 and 12) and found that BSRs exist in most of the closure areas, suggesting the trapping of free gas underneath the closed topographic highs. Similar situations also occur in the buried-anticlines, where the flat-lying strata that drape over the dipping strata may help to seal free gas underneath GHSZ.

In the rear segment of the lower accretionary wedge, a series of thrust faults tilts the hangingwall strata, forming monoclinal ridges or anticlinal ridges. Biogas produced from shallow marine sediments of slope basins and deep-seated gas-bearing fluids (thermogas) may migrate upward through permeable, dipping sandy layers of the hangingwall strata or brittle thrust fault zones toward the ridge crests. As a result, the source area for biogenic gas (i.e. gas kitchen) in the rear segment is relatively large, and numerous fluid migration paths may help to tap both shallow- and deep-seated gases. Therefore, we suggest that gas hydrates may occur widely and in many structural setting in the rear segment, as evidenced by the widespread distribution of BSRs in the rear segment (Fig. 13).

In the frontal segment, the strata are gently-dipping or flatlying, leading to a limited areal extent of gas kitchen. In addition, many tributaries of Penghu submarine -canyon cut across this area, and the biogas generated from shallow sediments may leak through the erosional gullies. Furthermore, most of thrust faults do not break the seafloor, and therefore deep-seated natural gas may not migrate upward to reach GHSZ. For these reasons, the gas source for forming gas hydrates in the frontal segment may be dominated by in situ biogenic gas sourced from synclinal areas, so that most BSRs only exist beneath ridge crests (i.e. ridge type).

In the South China Sea continental slope, the BSR is more abundant in the NE half than in the SW half of slope. A major listric normal fault located in the NE half of the slope cuts across deep strata and tilts them shelfward. Lin et al. (1993) reported that, beneath the shelf and slope, there exists a thermogenic gas kitchen supplying gas to the F-structure gas field in the north. The tilted beds and deep brittle fault zones may serve as conduits for tapping thermogenic gas sourced from this deep-seated gas kitchen. The gas-bearing fluids may migrate upward beneath the slope, forming
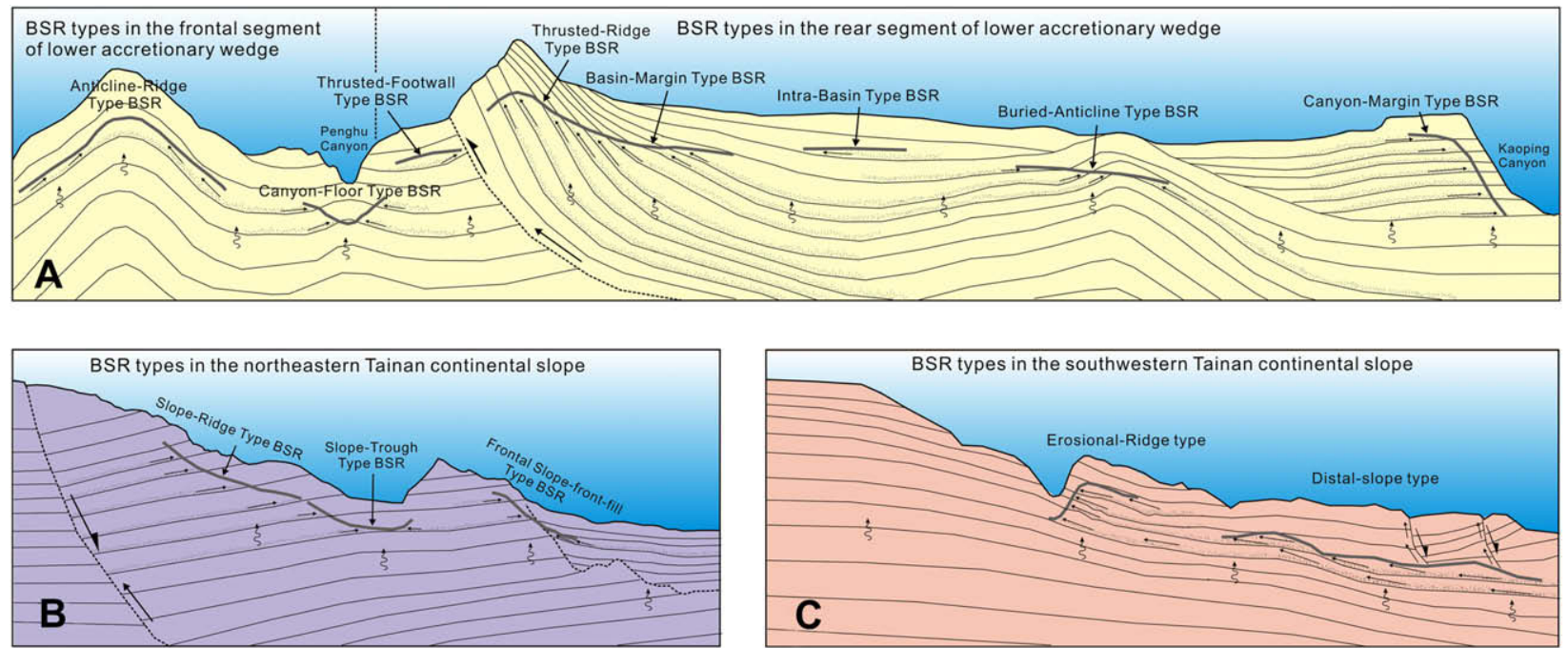

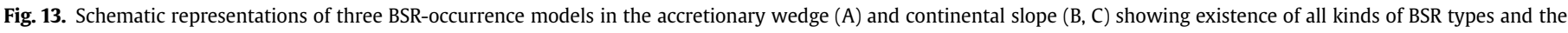
migration paths of gas-bearing fluids related to various structural styles. See Fig. 5 for symbol explanations. 
gas hydrates under favorable conditions and resulting in many BSRs that even exist beneath gullies and not only in topographic highs as is usually the case. By comparison, in the SW half of the slope, gas migration may be dominated by uphill, lateral migrating and buoyancy-driven flows as no deep cutting faults were found in this region, and BSRs are found preferentially beneath topographic highs.

\section{Conclusions}

We recognized a large number of BSRs in the lower-slope domain of the Taiwan accretionary wedge and its adjacent South China Sea continental slope. There is a correlation between distribution of BSRs, seafloor topography, and tectonic features. Four major occurrences of BSR types (ridge type, basin type, submarinecanyon type, and continental slope type) are recognized on the basis of the relationship of BSRs to topographic and structural features.

Abundant BSRs exist in the rear segment of the accretionary wedge and the NE portion of the South China Sea continental slope. The brittle thrust fault zones in the rear segment of accretionary wedge may provide gas conduits for deep gas-bearing fluids to migrate upward toward GHSZ. However, fewer BSRs are found in the frontal segment of accretionary wedge, and this is interpreted to result from limited gas-source area and the lack of deep-seated faults that cut through the GHSZ.

In the $\mathrm{NE}$ portion of the continental slope adjacent to the deformation front, a major normal fault develops in the upperslope with rotated strata in the hangingwall. These rotated beds together with the normal fault zone may provide conduits for upward movement of fluids. On the other hand, the sediments show a prograding wedge in the SW half of the studied continental slope. BSRs are sparse there and they occur mainly beneath remnant erosional ridges. Gas migration may be dominated by buoyancy-driven flows that migrate in an uphill direction and perpendicular to bathymetric contours.

\section{Acknowledgements}

We thank the captain and crew of the R/V Ocean Researcher I for their support in collecting the seismic data used in this study. We are grateful to George Spence and one anonymous reviewer for their constructive comments, which have greatly improved the quality of this paper. This study is supported by Central Geological Survey, Ministry of Economic Affairs, Taiwan, under grants of 5226902000-06-93-01, 5226902000-05-94-01, and 522690200005-95-01.

\section{References}

Ashi, J., Tokuyama, H., Taira, A., 2002. Distribution of methane hydrate BSRs and its implication for the prism growth in the Nankai Trough. Mar. Geol. 187, 177-191.

Baba, K., Yamada, Y., 2004. BSRs and associated reflections as an indicator of gas hydrate and free gas accumulation: an example of accretionary prism and forearc basin system along the Nankai Trough, off central Japan. Resour. Geol. 54 (1), 11-24.

Berndt, C., Bünz, S., Clayton, T., Mienert, J., Sounders, M., 2004. Seismic character of bottom simulating reflectors: examples from the mid-Norwegian margin. Mar Petrol. Geol. 21, 723-733.

Brooks, J.M., Kennicutt II, M.C., Fay, R.R., Mcdonald, T.J., Sassen, R., 1984. Thermogenic gas hydrates in the Gulf of Mexico. Science 225, 409-411.

Bryan, G.M., 1974. In situ indications of gas hydrates. In: Kaplan, I.R. (Ed.), Natural Gases in Marine Sediments. Plenum Press, New York, pp. 299-308.

Caine, J.S., Evans, J.P., Forster, C.B., 1996. Fault zone architecture and permeability structure. Geology 24, 1025-1028.

Cheng, W.-B., Lee, C.-S., Liu, C.-S., Schnurle, P., Lin, S.-S., Tsai, H.-R., 2006. Velocity structure in marine sediments with gas hydrate reflectors in offshore SW Taiwan, from OBS data tomography. Terr. Atmos. Ocean. Sci. 17, 739-756.
Chi, W.-C., Reed, D.L., Liu, C.-S., Lundberg, N., 1998. Distribution of the bottomsimulating reflector in the offshore Taiwan collision zone. Terr. Atmos. Ocean. Sci. 9 (4), 779-794

Chi, W.-C., Reed, D.L., Tsai, C.-C., 2006. Gas hydrate stability zone in offshore southern Taiwan. Terr. Atmos. Ocean. Sci. 17, 829-843.

Chiang, C.-S., Yu, H.-S., Chou, Y.-W., 2004. Characteristics of the wedge-top depozone of the southern Taiwan foreland basin system. Basin Res. 16, 65-78.

Chiu, J.-K., Tseng, W.-H., Liu, C.-S., 2006. Distribution of gassy sediments and mud volcanoes offshore southwestern Taiwan. Terr. Atmos. Ocean. Sci. 17, 703-722.

Chow, J., Lee, J.-S., Sun, R., Liu, C.-S., Lundberg, N., 2000. Characteristics of the bottom simulating reflectors near mud diapirs: offshore southwestern Taiwan. Geo-Mar. Lett. 20, 3-9.

Chuang, P.-C., Yang, T.F., Lin, S., Lee, H.-F., Lan, T.-F., Hong, W.-L., Liu, C.-S., Chen, J.-C., Wang, Y., 2006. Extremely high methane concentration in bottom water and cored sediments from offshore southwestern Taiwan. Terr. Atmos. Ocean. Sci. 17, 903-920.

Colwell, F., Matsumoto, R., Reed, D., 2004. A review of the gas hydrates, geology, and biology of the Nankai Trough. Chem. Geol. 205, 391-404.

Dadson, S.J., Hovius, N., Chen, H., Dade, B., Hsieh, M.-L., Willett, S.D., Hu, J.-C., Horng, M.J., Chen, M.-C., Stark, C.P., Lague, D., Lin, J.-C., 2003. Links between erosion, runoff variability and seismicity in the Taiwan orogen. Nature 426, 648-651.

Dillon, W.P., Paull, C.K., 1983. Marine gas hydrate II, geophysical evidence. In: Cox, J.L. (Ed.), Natural Gas Hydrates: Properties, Occurrence and Recovery. Butterworth-Heinmann, Stoneham, MA.

Dillon, W.P., Fehlhaber, K., Coleman, D.F., Lee, M.W., 1993. Gas hydrates on the Atlantic continental margin of the United States - controls on concentration. In: Howell, D.G. (Ed.), The Future of Energy Gases. U.S. Geol. Surv. Professional Paper 1570, pp. 313-330.

Ecker, C., Dvorkin, J., Nur, A., 1998. Sediments with gas hydrates: Internal structure from seismic AVO. Geophysics 63, 1659-1669.

Gieskes, J.M., Vrolijk, P., Blanc, G., 1990. Hydrogeochemistry of the Northern Barbados accretionary complex transect: Ocean Drilling Program Leg 110. J. Geophys. Res. 95 (B6), 8809-8818.

Haacke, R.R., Westbrook, G.K., Riley, M.S., 2008. Controls on the formation and stability of gas hydrate-related bottom-simulating reflectors (BSRs): a case study from the west Svalbard continental slope. J. Geophys. Res. 113, B05104 doi:10.1029/2007JB005200.

Hein, J.R., Scholl, D.W., Barron, J.A., Jones, M.G., Miller, J., 1978. Diagenesis of late Cenozoic diatomaceous deposits and formation of the bottom-simulating reflector in the southern Bering Sea. Sedimentology 25, 155-181.

Holbrook, W. ., 2001. Seismic studies of the Blake Ridge: implications for hydrate distribution, methane expulsion, and free gas dynamics. In: Paull, C.K. Dillon, W.P. (Eds.), Natural Gas Hydrates: Occurrence, Distribution, and Detection. Geophys. Monogr. 124. Am. Geophys. Union, Washington, DC, pp. 235-256.

Holbrook, W.S., Hoskins, H., Wood, W.T., Stephen, R.A., Lizarralde, D., Leg 164 Science Party, 1996. Methane hydrate and free gas on the Blake Ridge from vertical seismic profiling. Science 273, 1840-1843.

Horng, C.-S., Chen, K.-H., 2006. Complicated magnetic mineral assemblages in marine sediments offshore of southwestern Taiwan: possible influence of methane flux on the early diagenetic process. Terr. Atmos. Ocean. Sci. 17, 1009-1026.

Hu, C.-C., Huang, F.F.-W., Wang, S.-H., Kuo, C.-L., Wu, S.-H., Fuh, S.-C., Shen, H.-C., Huang, S.-T., Ting, H.-H., Hsu, S.-H., Lin, L.-H., Oung, J.-N., Chiu, J.-H., Lee, K.-F. Hu, C.-C., Yang, H.-H., Wu, H.-B., Chang, C.-J., Chang, C.-F., 1999. Comprehensive assessment of hydrocarbon potential of the Tainan basin. Bull. Explor. Prod. Res. CPC Corp 22, 26-46 (in Chinese).

Huang, C.-Y., Yuan, P.-B., Lin, C.-W., Wang, T.-K., Chang, C.-P., 2000. Geodynamic processes of Taiwan arc-continent collision and comparison with analogs in Timor, Papua New Guinea, Urals and Corsica. Tectonophysics 325, 1-21.

Huang, C.-Y., Chien, C.-W., Zhao, M., Li, H.-C., Iizuka, Y., 2006. Geological study of active cold seeps in the syn-collision accretionary prism Kaoping slope off SW Taiwan. Terr. Atmos. Ocean. Sci. 17, 679-702.

Hyndman, R.D., Davis, E.E., 1992. A mechanism for the formation of methane hydrate and seafloor bottom-simulating-reflectors by vertical fluid expulsion. J Geophys. Res. 97, 910-924.

Hyndman, R.D., Spence, G.D., Chapman, R., Riedel, M., Edwards, R.N., 2001. Geophysical studies of marine gas hydrate in Northern Cascadia. In: Charles, K.P., William, P.D. (Eds.), Natural Gas Hydrates: Occurrence Distribution and Detection. Geophysical Monograph Series 124. Amer. Geophys. Union, pp. 273-295.

Jiang, W.-T., Chen, J.-C., Huang, B.-J., Chen, C.-J., Lee, Y.-T., Huang, P.-R., Lung, C.-C., Huang, S.-W., 2006. Mineralogy and physical properties of cored sediments from the gas hydrate potential area of offshore southwestern Taiwan. Terr. Atmos. Ocean. Sci. 17, 981-1007.

Kao, H., Huang, G.-C., Liu, C.-S., 2000. Transition from oblique subduction to collision in the northern Luzon arc-Taiwan region: constraints from bathymetry and seismic observations. J. Geophys. Res. 105, 3059-3079.

Kastner, M., Keene, J.B., Gieskes, J.M., 1977. Diagenesis of siliceous oozes-I. Chemical controls on the rate of opal-A to opal-CT transformation an experimental study. Geochim. Cosmochim. Acta 41, 1041-1059.

Kvenvolden, K.A., Kastner, M., 1990. Gas hydrate of the Peruvian outer continental margin, in: Suess, E., von Huene, R. (Eds.), Proceedings of the Ocean Drilling Program, Scientific Results, 112, College Station, Ocean Drilling Program, pp. 517-526.

Langseth, M.G., Moore, J.C., 1990. Introduction to special section on the role of fluids in sediment accretion, deformation, diagenesis, and metamorphism in subduction zones. J. Geophys. Res. 95 (B6), 8737-8741. 
Lee, M.W., Dillon, W.P., 2001. Amplitude blanking related to the pore-filling of gas hydrate in sediments. Mar. Geophys. Res. 22, 101-109.

Lee, G.H., Kim, H.-J., Jou, H.-T., Cho, H.-M., 2003. Opal-A/opal-CT phase boundary inferred from bottom-simulating reflectors in the southern South Korea Plateau, East Sea (Sea of Japan). Geophys. Res. Lett. 30 (24), 2238.

Lin, L.-H., Chiu, J.-H., Wu, S.-H., 1993. The hydrocarbon generation and migration study in the Central Uplifted Zone, Tainan Basin. Bull. Explor. Prod. Res. CPC Corp 16, 349-369 (in Chinese).

Lin, A.T., Watts, A.B., Hesselbo, S.P., 2003. Cenozoic stratigraphy and subsidence history of the South China Sea margin in the Taiwan region. Basin Research 15 (4), 453-478.

Lin, S., Hsieh, W.-C., Lim, Y.-C., Yang, T.F., Liu, C.-S., Wang, Y., 2006. Methane migration and its influence on sulfate reduction in the Good Weather Ridge region, South China Sea continental margin sediments. Terr. Atmos. Ocean. Sci. 17, 883-902.

Lin, A.T., Liu, C.-S., Lin, C.-C., Schnurle, P., Chen, G.-Y., Liao, W.-Z., Chuang, H.-R Teng, L.S., Wu, M.-S., 2008. Tectonic features associated with the overriding of an accretionary wedge on top of a rifted continental margin: an example from Taiwan. Mar. Geol. 255, 186-203.

Liu, C.-S., Liu, S.-Y., Kuo, B.-Y., Lundberg, N., Reed, D., 1992. Characteristics of the gravity and magnetic anomalies off southern Taiwan. Acta Geol. Taiwan 30, 123-130.

Liu, C.-S., Huang, I.-L., Teng, L.S., 1997. Structural features off southwestern Taiwan. Mar. Geol. 137, 305-319.

Liu, C.-S., Liu, S.-Y., Lallemand, S., Lundberg, N., Reed, D.L., 1998. Digital elevation model offshore Taiwan and its tectonic implication. Terr. Atmos. Ocean. Sci. 9, 705-738.

Liu, C.-S., Schnurle, P., Wang, Y., Chuang, S.-H., Chen, S.-C., Hsiuan, T.-H., 2006. Distribution and characters of gas hydrate offshore of southwestern Taiwan. Terr. Atmos. Ocean. Sci. 17, 615-644.

Lundberg, N., Reed, D., Liu, C.-S., Lieske Jr., J., 1992. Structural controls on orogenic sedimentation, submarine Taiwan collision. Acta Geol. Taiwan 30, 131-140.

MacKay, M.E., Jarrard, R.D., Westbrook, G.K., Hyndman, R.D., 1994. Origin of bottomsimulating reflectors: geophysical evidence from the Cascadia accretionary prism. Geology 22, 459-462.

Marchesi, J.R., Weightman, A.J., Cragg, B.A., Parkes, R.J., Fry, J.C., 2001. Methanogen and bacterial diversity and distribution in deep gas hydrate sediments from the Cascadia margin as revealed by $16 \mathrm{~S}$ rRNA molecular analysis. Microbiol. Ecol 34 (3), 221-228

Mason, E.A., Malinauskas, A.P., Evans III, R.B., 1967. Flow and diffusion of gases in porous media. J. Chem. Phys. 46 (8), 3199-3216.

McDonnell, S.L., Max, M.D., Cherkis, N.Z., Czarnecki, M.F., 2000. Tectono-sedimentary controls on the likelihood of gas hydrate occurrence near Taiwan. Mar. Petrol. Geol. 17, 929-936.

Miller, J.J., Lee, M.W., von Huene, R., 1991. An analysis of a seismic reflection from the base of a gas hydrate zone. Am. Ass. Petrol. Geol. Bull. 75, 910-924.

Moore, G.F., Shipley, T.H., Stoffa, P.L., Karig, D.E., Taira, A., Kuramoto, S., Tokuyama, H., Suyehiro, K., 1990. Structure of the Nankai Trough accretionary zone from multichannel seismic reflection data. J. Geophys. Res. 95, 8753-8765.

Oung, J.-N., Lee, C.-Y., Lee, C.-S., Kuo, C.-L., 2006. Geochemical study on hydrocarbon gases in seafloor sediments, southwestern offshore Taiwan - implications in the potential occurrence of gas hydrates. Terr. Atmos. Ocean. Sci. 17, 921-931.

Paull, C.K., Ussler, W., Borowski, W.S., 1994. Sources of biogenic methane to form marine gas hydrates: In-situ production or upward migration, in: Sloan, E.D. (Ed.), International Conference on Natural Gas Hydrates. Annals of the New York Academy of Sciences, vol. 715, pp. 392-409.

Paull, C.K., Borowski, W.S., Rodriguez, N.M., 1998. Marine Gas Hydrate Inventory: Preliminary Results of ODP Leg 164 and Implications for Gas Venting and Slumping Associated with the Blake Ridge Gas Hydrate Field. In: Geological Society, vol. 137. Special Publications, London, pp. 153-160.
Pecher, I.A., Minshull, T.A., Singh, S.C., VonHuene, R., 1996. Velocity structure of a bottom simulating reflector offshore Peru: results from full waveform inversion. Earth Planet. Sci. Lett. 139, 459-469.

Reed, D.L., Lundberg, N., Liu, C.-S., Kuo, B.-Y., 1992. Structural relations along the margins of the offshore Taiwan accretionary wedge: implication for accretion and crustal kinematics. Acta Geol. Taiwan 30, 105-122.

Riedel, M., Willoughby, E.C., Chen, M.A., He, T., Novosel, I., Schwalengerg, K., Hyndman, R.D., Spence, G.D., Chapman, N.R., Edwards, R.N., 2006. Gas hydrate on the northern Cascadia margin: regional geophysics and structural framework. Proc. IODP 311, 1-28.

Sassen, R., Joye, S., Sweet, S.T., DeFreitas, D.A., Milkov, A.V., MacDonald, I.R., 1999. Thermogenic gas hydrates and hydrocarbon gases in complex chemosynthetic communities, Gulf of Mexico continental slope. Org. Geochem 30, 485-497.

Schnurle, P., Hsiuan, T.-H., Liu, C.-S., 1999. Constraints on free gas and gas hydrate bearing sediments from multi-channel seismic data, offshore southwestern Taiwan. Petrol. Geol. Taiwan 33, 21-42.

Schnurle, P., Liu, C.-S., Lee, C.-S., 2006. Acoustic and shear-wave velocities in hydrate-bearing sediments offshore southwestern Taiwan: tomography, converted waves analysis and reverse-time migration of OBS records. Terr. Atmos. Ocean. Sci. 17, 757-779.

Shipley, T.H., Houston, M.H., Buffler, R.T., Shaub, F.J., McMillen, K.J., Ladd, J.W., Worzel, J.L., 1979. Seismic evidence for widespread possible gas hydrate horizons on continental slopes and rises. Am. Ass. Petrol. Geol. Bull. 63, 2204-2213.

Shipley, T.H., Stoffa, P.L., Dean, D.F., 1990. Underthrust sediments, fluid migration paths and mud volcanoes associated with the accretionary wedge off Costa Rica: middle America Trench. J. Geophys. Res. 95, 8743-8752.

Shipley, T.H., Ogawa, Y., Blum, P., et al., 1995. Proceedings of the Ocean Drilling Program, Initial Results, 156. College Station, Texas (Ocean Drilling Program).

Shyu, C.-T., Hsu, S.-K., Liu, C.-S., 1998. Heat flows off southwest Taiwan: measurements over mud diapirs and estimations from bottom simulating reflectors. Terr. Atmos. Ocean. Sci. 9, 795-812.

Shyu, C.-T., Chen, Y.-J., Chiang, S.-T., Liu, C.-S., 2006. Heat flow measurements over bottom simulating reflectors, offshore southwestern Taiwan. Terr. Atmos. Ocean. Sci. 17, 845-869.

Sun, S.-C., Liu, C.-S., 1993. Mud diapirs and submarine channel deposits in offshore Kaohsiung-Hengchun, southwest Taiwan. Petrol. Geol. Taiwan 28, 1-14.

Tinivella, U., Lodolo, E., 2000. The Blake Ridge bottom-simulating reflector transect: tomographic velocity field and theoretical model to estimate methane hydrate quantities, in: Paull, C.K., Matsumoto, R., Wallace, P.J., Dillon, W.P. (Eds.), Proceedings of the Ocean Drilling Program, Scientific Results, 164, College Station, Texas, pp. 273-281.

Tucker, P.M., Yorston, H.J., 1973. Pitfalls in Seismic Interpretation. Society of Exploration Geophysicists, Tulsa, Oklahoma, 50 pp.

VonHuene, R., Pecher, I.A., 1999. Vertical tectonics and the origins of BSR's along the Peru margin. Earth Planet. Sci. Lett. 166, 47-55.

Wang, T.-K., Chen, C.-W., Lee, C.-S., Yang, B.-C., 2006. MCS/OBS imaging of gas hydrate along profile ORIII1087-B at the continental slope of the northern SCS. 2006 Taiwan Gas Hydrate Workshop Proceedings, p. 29.

Yang, K.-M., Ting, H.-H., Yuan, J., 1991. Structural styles and tectonic modes of Neogene extensional tectonics in southwestern Taiwan: implications for hydrocarbon exploration. Petrol. Geol. Taiwan 26, 1-31.

Yang, T.F., Yeh, G.-H., Fu, C.-C., Wang, C.-C., Lan, T.-F., Lee, H.-F., Chen, C.-H., Walia, V., Sung, Q.-C., 2004. Composition and exhalation flux of gases from mud volcanoes in Taiwan. Environmental Geol. 46, 1003-1011.

Yen, J.-Y., Lundberg, N., 2006. Sediment compositions in offshore southern Taiwan and their relations to the source rocks in modern arc-continent collision zone. Mar. Geol. 225, 247-263.

Yuan, T., Spence, G.D., Hyndman, R.D., 1999. Seismic velocity studies of a gas hydrate bottom-simulating reflector on the northern Cascadia continental margin: amplitude modeling and full waveform inversion. J. Geophys. Res. 104, 1179-1191. 